\title{
Mobbing Aracı Olarak Ölçme ve Değerlendirme Ölçeği
}

\author{
Süleyman Nihat ŞAD \\ İnönü Üniversitesi, Eğitim Fakültesi, Eğitim Bilimleri Bölümü, Malatya \\ nihat.sad@inonu.edu.tr \\ ORCID ID: https://orcid.org/0000-0002-3169-2375 \\ Niyazi ÖZER \\ İnönü Üniversitesi, Eğitim Fakültesi, Eğitim Bilimleri Bölümü, Malatya \\ niyazi.ozer@inonu.edu.tr \\ ORCID ID: https://orcid.org/0000-0001-7745-6645 \\ Meltem YURTÇU \\ İnönü Üniversitesi, Eğitim Fakültesi, Eğitim Bilimleri Bölümü, Malatya \\ meltem.yurtcu@inonu.edu.tr \\ ORCID ID: https://orcid.org/0000-0003-3303-5093 \\ Nuri ERDEMIR \\ İnönü Üniversitesi, Eğitim Fakültesi, Eğitim Bilimleri Bölümü, Malatya \\ nuri.erdemir@inonu.edu.tr \\ ORCID ID: https://orcid.org/0000-0002-5106-7884
}

Araştırma Makalesi

DOI: $10.31592 /$ aeusbed.612591

Gelis tarihi: 28.08.2019

Revize Tarihi: 10.12 .2019

Kabul tarihi: 11.12.2019

\section{Atıf Bilgisi}

Şad, S. N., Özer, N., Yurtçu, M. ve Erdemir, N. (2019). Mobbing aracı olarak ölçme ve değerlendirme ölçeği. Ahi Evran Üniversitesi Sosyal Bilimler Enstitüsü Dergisi, 5(2), 220-236.

\section{ÖZ}

Öğretim elemanlarının pedagojik yetersizlikleri, ölçme ve değerlendirme süreçlerinin öğrenciler üzerinde bir baskı ya da cezalandırma aracına dönüşmesine neden olabilir. Bu suistimalin süreğen hale gelmesi ise öğrencilerde psikolojik yıldırmaya (mobbing) yol açabilir. Üniversite öğrencilerinin ölçme değerlendirme süreçlerinde mobbinge maruz kalma düzeylerini ölçebilecek geçerli, güvenilir ve kullanışlı bir ölçek geliştirmeyi amaçlayan bu araştırma bir karma yöntem araştırması olarak desenlemiştir. Bu amaçla "Mobbing Aracı olarak Ölçme-Değerlendirme Ölçeği”nin [MAÖDÖ] maddeleri nitel bir veri toplama ve analiz süreci ile geliştirilmiş ve ardından psikometrik özellikleri İnönü Üniversitesine bağlı 23 farklı MYO/Fakülte/Enstitü'de öğrenim görmekte olan 1850 öğrenciden elde edilen veriler analiz edilerek incelenmiştir. Yapılan açımlayıcı faktör analizi sonucunda tek faktörden oluşan ölçeğin makul düzeyde varyans açıklama oranına (\%63), yüksek faktör yük değerlerine (.745-.843) ve madde-toplam korelasyon katsayılarına ( $\mathrm{r}=.652-.770)$ sahip olduğu; takip eden doğrulayıcı faktör analizinde ise yapının kabuledilebilir ya da mükemmel uyum iyiliği değerleriyle doğrulandığ $1\left[\mathrm{X}^{2} / \mathrm{sd}=42.439 / 12=3.537 ; \mathrm{RMR}=0.042 ; \mathrm{GFI}=0.986\right.$, AGFI= 0.968; CFI= 0.991; NFI= 0.987; RMSEA=0.054] görülmüştür. Ayrıca ölçek maddelerinin ortalama varyans açıklama değerleri $(\mathrm{AVE}=.56)$ ve kompozit güvenirlik $(\mathrm{CR}=.90)$ katsayılarından hareketle yapının yakınsak geçerliliğinin ve güvenilirliğinin yeterli olduğu anlaşılmıştır. Ölçeğin Cronbach Alfa $(\alpha=.902)$ ve Guttman test yarılama $(r=.878)$ yöntemleriyle hesaplanan içtutarlılık katsayıları da ölçekten elde edilen puanların yüksek düzeyde güvenirliğe sahip olduğunu göstermektedir. Toplam 7 maddeden oluşan 5'li Likert formatındaki MAÖDÖ'nden alınan minimum ve maksimum puanlar 7-35 arasında değişmekte olup alınan puanların artması öğrencilerin ölçme değerlendirme aracılığıyla mobbinge maruz kalma düzeylerinin de arttı̆̆ını göstermektedir.

Anahtar Kelimeler: Mobing, ölçme ve değerlendirme, yükseköğretim.

\section{Mobbing Through Measurement and Evaluation Scale}

\begin{abstract}
The pedagogical insufficiency of the faculty staff can turn the measurement and evaluation process into a means of pressure or punishment on students. When this mistreatment becomes persistent, it may lead to mobbing on students. This research, which aims to develop a valid, reliable and useful scale to measure the university students' levels of exposure to mobbing through measurement and evaluation processes, has been designed as a mixed method research. To this end, the items of "Mobbing through Measurement and Evaluation Scale" [MMES] were developed through a qualitative data collection and analysis process, and its psychometric properties were analyzed with the data obtained from 1850 students studying at 23 different Vocational Schools/Faculties/Institutes of İnönü University. The exploratory factor analysis yielded a single factor construct with a favorible variance explanation rate (63\%), high loading values (.745- .843) and itemtotal correlation coefficients $(r=.652-.770)$; and the successive confirmatory factor analysis proved that the
\end{abstract}


construct was confirmed by acceptable or excellent goodness of fit values $\left[\mathrm{x}^{2} / \mathrm{df}=42,439 / 12=3,537\right.$; $\mathrm{RMR}=0.042 ; \mathrm{GFI}=0.986, \mathrm{AGFI}=0.968 ; \mathrm{CFI}=0.991 ; \mathrm{NFI}=0.987 ; \mathrm{RMSEA}=0.054]$. In addition, average variance explanation value $(\mathrm{AVE}=, 56)$ and composite reliability $(\mathrm{CR}=.90)$ coefficients suggested that the convergent validity and reliability of the structure was sufficient. The Cronbach's alpha $(\alpha=, 902)$ and Guttman split-half $(r=.878)$ reliability coefficients of the scale indicated that the scores obtained from the scale have a high level of reliability. The minimum and maximum scores obtained from the 7-item 5-point Likert format ranged between 7 and 35 suggesting that the increase in the scores implies that mobbing exposure levels of the students also increases.

Keywords: Mobbing, measurement and evaluation, higher education.

\section{Giriş}

Eğitim sürecinin farklı aşamalarında öğrencilerin kazanımlara ne düzeyde sahip olduklarını belirlemek amacıyla ölçme ve değerlendirmeye başvurulur. Yapılan ölçme ve değerlendirmenin sonuçlarından hareketle öğrenciler, öğretmenler, okullar ve eğitim programları hakkında sonuçlar çıkarılır, geleceğe yönelik kararlar ve politikalar belirlenir. Ĕ̆itim-öğretim sürecinde değerlendirme, kullanıldığ1 amaca yönelik olarak üçe ayrılmaktadır. Bunlar; tanılayıcı değerlendirme (diagnostic assessment), biçimlendirici değerlendirme (formative assessment) ve düzey belirleyici değerlendirmedir (summative assessment) (Torrance ve Pryor, 1998). Tanılayıc1 değerlendirme, programa başlangıçta öğrencilerin ön koşul şartları sağlayıp sağlamadığını ortaya koymak ve bireylerin ön bilgileri arası farklı1ıkları görmek amacı ile kullanılmaktadır. Biçimlendirici değerlendirme, süreç içerisinde öğrencinin öğrenme ihtiyaçlarına hizmet etmekte ve gerekli düzeltmeleri yaparak öğretim programının etkililiğini arttırılabilmektedir (Wen ve Tsai, 2006). Biçimlendirici değerlendirme, yalnızca etkinlikten sonra başarıyı veya başarısızlığı belirlemeyi amaçlamak yerine, başarıyı en üst seviyeye çıkarmayı, öğrenmeyi geliştirmeyi amaçlayan telafi edici bir süreçtir. Dolayısıyla, formative değerlendirme, öğrenciye sadece sayısal bir not dönütü vermeyi değil, güçlü ve zayıf yönlerle ilgili zengin ve ayrıntılı geri bildirim vermeyi amaç edinir (Bahar, Nartgün, Durmuş ve Bıçak, 2012; Topping, 1998; Topping, Smith, Swanson ve Elliot, 2000). Düzey belirleyici değerlendirme ise program sonunda öğrencilerin hedeflenen davranışları kazanıp kazanmadığını ve/veya ne düzeyde kazandıklarını ortaya koymak amacı ile kullanılmaktadır. Bu sayede programın yeterliliği ve etkililiği de sorgulanabilmektedir.

Yapılma amaçlarına göre ölçme ve değerlendirme uygulamalarının farklı zamanlarda ve türlerde kullanılabileceği görülmektedir. $\mathrm{Bu}$ amaç süreç boyunca farklı yöntem ve teknikleri ile öğrencilerin öğrenme eksikliklerinin tespit edilmesi ve giderilmesi, öğrencilerin öğrenme düzeylerinin artırılabilmesi, öğretim hizmetlerinin değerlendirilmesi, öğrencilerin yetenekleri doğrultusunda yönlendirilmesi ve öğrencilerin başarılarını yansıtacak daha güvenilir notlar verilmesi olabileceği gibi başarı-başarısızlık ve yeterli-yetersizlik ile ilgili bir kesin saptamalar yapmak da olabilir.

Geleneksel ölçme ve değerlendirme yaklaşımında sürecin büyük ölçüde öğretmen merkezli olması (Adediwura, 2012; Sung, Chang, Chiou ve Hou, 2005), öğrencinin kendi kapasitesinin farkına varmasını engellemekte ve özdeğerlendirme ve özdenetim becerilerinin gelişimini olumsuz yönde etkilemektedir (Cihanoğlu, 2008). Ancak çağdaş ölçme değerlendirme uygulamalarında sadece öğrencilerin mevcut bilgisini bir notla belirleyerek başarı ya da başarısızlığına karar vermekle yetinmeyip, öğrencileri daha iyi yönlendirebilmek amacıyla süreci gözlemlemek için kullanılmalı (Uysal, 2008), öğrencilerin kendi performanslarıyla ilgili görüşlerine de önem verilmelidir (Oskarsson,1981). Bu yaklaşım günümüzde öğrenme ve öğretme süreçlerinde öğretmen merkezli bir anlayıştan öğrenci merkezli anlayışa doğru geçişin yaşanmasına neden olmuştur (Black ve William, 1998; Broadfoot ve Black, 2004; Mok, 2010; Uysal, 2008). Dolayısıyla sonuç temelli öğretmen merkezli geleneksel ölçme ve değerlendirme yaklaşımlan giderek daha gerçekçi, özgün, katılımcı, süreç temelli çağdaş/tamamlayıcı/alternatif yaklaşımlara doğru kaymıştır (Cihanoğlu, 2008; Ploegh, Tillema ve Segers, 2009). Öğrenciyi ölçme-değerlendirme sürecinde pasif tutan geleneksel yaklaşımların aksine hem süreci hem de ürünü temele alan çağdaş ölçme değerlendirme yaklaşımları; öğrencilerin yaşam boyu öğrenme, yansıtıcı düşünme, eleştirel bakış açısı geliştirme, kendini değerlendirme, problem çözme, yorum yapabilme, özdenetim gibi becerileri geliştirebilmelerine firsat vermektedir (Birjandi ve Tamjid, 2012; Sambell ve McDowell 1998; Uysal, 2008; Wen ve Tsai, 2006; Yurdabakan, 2012). 
Alanda hem geleneksel hem de çağdaş ölçme ve değerlendirme araçlarının birlikte kullanılması, ölçme değerlendirmenin daha geniş ve ayrıntılı bir alan haline gelmesine neden olmuş, ölçme değerlendirme araçlarının ve yöntemlerinin çok daha özenli bir şekilde kullanılmasını gerekli kılmıştır. Dolayısıyla ölçme değerlendirme süreçlerinin nitelikli bir şekilde uygulanması için ihtiyaç duyulan ölçütler konusunda tartışmalar başlamıştır (Birenbaum, 2007). Bu ölçütlerin başında ise öğretim hizmetini sunan kişinin ölçme ve değerlendirme araçları ve yöntemlerine ilişkin yeterlilik düzeyi gelmektedir. Ölçme değerlendirme konusunda yeterli pedagojik yeterliliğe sahip bir öğretmenin geleneksel ve çağdaş ölçme değerlendirme yaklaşımlarını ayırt edebilmesi ve ders planlarında her iki yaklaşımı da doğru bir şekilde uygulaması beklenir. Ölçme ve değerlendirme araçlarını ve yöntemlerini doğru kullanmayı bilmeyen öğretmenlerin, öğrencilerini ve eğitim sürecinin niteliğini olumsuz yönde etkileyebilecek yanlış uygulamalar yapması muhtemeldir. $\mathrm{Bu}$ yanlış uygulamalar, öğretmenlerin ölçme ve değerlendirme sürecini bir cezalandırma ya da baskı aracı olarak kullanmaları gibi mesleki etiğe aykırı davranışlara neden olabilir. Bu yanlış uygulamaların süreğen hale gelmesi ise öğrencilerde psikolojik yıldırmaya (mobbing) yol açabilir.

Günümüzde şiddet olgusunun fiziksel şiddet, duysusal şiddet, cinsel şiddet, akran zorbalığ 1 , siber zorbalık gibi çok farklı türlerde açık ya da gizli bir şekilde hızla yayıldığı görülmektedir. Son yıllarda, özellikle rekabetin ön plana çıktığı ülkelerde yaygın olarak gözlemlenen mobbing davranış1 bireylerin yaşamını birçok açıdan olumsuz etkilemektedir. Mobbing kavramı; kısa boylu bir hayvan grubunun daha uzun boylu hayvanlara karşı saldırılarını tanımlamak amacıyla ilk defa 1970'de Konrad Lorenz tarafından kullanılmış, insanlarda ise öğrencilerin birbirine uyguladığı yıldırıcı davranışlarını tanımlamak amacıyla 1970'li yıllarda Heinemann tarafından kullanılmıştır (Akgeyik, Güngör-Delen ve Uşen, 2013). Heinemann çocuklardan oluşan küçük grupların, tek ve güçsüz bir çocuğa karşı giriştiği zarar verici saldırgan davranışları mobbing kavramı ile tanımlamıştır (Tınaz, Bayram ve Ergin, 2008). Brodsky (1976), mobbing kavramını "bir bireyin iş yerinde bir başkasını yıpratmak, engel olmak ya da eziyet etmek için sürekli ve tekrar eden davranışlarda bulunması olarak tanımlamıştır." (Akt. Laleoğlu ve Özmete, 2013, s. 11). Günümüzde ise mobbing kavramının popülerlik kazanmasında şiddet ile ilgili yasal düzenlemelerin gözden geçirilmesi ve bireysel farkındalıkların artması etkili olmuştur (Laleoğlu ve Özmete, 2013). Mobbing kavramı genel olarak, düşünce ve inanç farklılığından kıskançlık ve cinsiyetçiliğe kadar farklı nedenlerden oluşabilen, birey ya da bireyler tarafından sistematik olarak düşmanca ve ahlak dışı bir iletişim yoluyla bir başka bireye yönelik uygulanan psikolojik yıldırma olarak tanımlanmaktadır (Leymann, 1996). Gün (2010) ise mobbingi, bir veya birden fazla birey tarafından birçok nedenle doğrudan ya da dolaylı olarak başka bir bireye dönük sistemli ve sürekli, sözlü ya da sözsüz davranışlar şeklinde yapılan ve bireyi psikolojik olarak olumsuz etkileyen saldırılar" şeklinde tanımlamaktadır. Yukarıda değinilen tanımlara genel olarak bakıldığında güç dengesizliği, saldırgan davranış, tekrarlanma ve uzun süreklilik ortak ögeler olarak yer alır (Çamurluoğlu ve Poussard, 2017). İçerdiği saldırgan ya da hakaret içeren davranışlar, mobbinge maruz kalan bireyin kendisini tehdit altında ve aşağılanmış hissetmesine neden olurken özgüvenini zayıflatır ve bireyi yoğun stres altında bırakır (Tutar, 2004).

Alanyazında mobbing kavramı psikolojik taciz, psikolojik yıldırma, psikolojik yıldırı, psikolojik bask1, mobbing vb. farklı isimler altında yoğun ilgi görmüş ve çok sayıda lisansüstü teze ve makaleye konu olmuştur. YÖK ulusal tez merkezinde 2019 Mayıs ayı itibariyle yukarıda sayılan anahtar kelimelerle yapılan taramada yaklaşık beş yüz çalışmaya ulaşılmaktadır. Ulaşılan bu çalışmalar incelendiğinde, mobbingle ilgili yapılan araştırmaların daha çok eğitim ve sağlık kurumlarında çalışan bireylere dönük (Çivilidağ, 2011; Elkıran, 2017; Erdemir, 2014; Karakoç, 2012; Saraç, 2018; Sarı, 2018; Taştan, 2017) yapıldığı görülmektedir. Söz konusu araştırmalarda mobbingin daha çok yöneticiler tarafından personele dönük olarak uygulandığ 1 belirtilse de son dönemlerde basına yansıyan haberler bazı yükseköğretim öğrencilerinin ders başarısı, sınavlar, notlar vb. gerekçelerle ögretim elemanlarına dönük saldırı ve şiddet davranışlarında bulunduğunu ortaya koymaktadır [British Broadcasting Corporation (BBC), 2019]. Diğer taraftan Türkiye'de yapılan çalışmalarda öğretmen veya öğretim elemanlarına yönelik olarak yapılan mobbing konusunda çalışmalara rastlanırken, öğretmen veya öğretim elemanları tarafından öğrencilere yönelik uygulanan mobbinge ilişkin çalışmalara rastlanmamıştır. Ancak her kademeden öğrenci, eğitimin doğası gereği 
mobbingin belirleyici özelliklerinden biri olan astlık-üslük ilişkilerine dayalı dikey iletişim süreçlerini bir şekilde deneyimlemektedir.

Öğrencilerin okuldaki eğitim-öğretim faaliyetleri esnasında mobbinge maruz kalabilecekleri durumlardan biri de ölçme ve değerlendirme süreçleridir. Son dönemlerde basında yer alan bazı haberlerde de öğretim elemanlarının ölçme değerlendirme süreçlerini bir baskı ya da taciz aracı olarak kullandığına dair iddialara yer verilmektedir [Cable News Network (CNN TÜRK), 2019]. Ölçme ve değerlendirme süreçlerini bilimsel ilkeler çerçevesinde yürütmeyen bir öğretmenin ya da öğretim elemanının sınav sonuçlarının değerlendirilmesinde ayrımcılık yapması ya da sınavları gereğinden zor hazırlaması öğrencilerin mobbinge maruz kalmasına yol açabilir. Benzer şekilde sınav süresinin sınav içeriği ile uyumsuz olması, sınavda derste işlemeyen içeriklerden soru hazırlanması, öğrencilerin notla tehdit edilmesi, öğrencilerin sınavla ilgili eleştirilerinin dikkate alınmaması öğrencilerin dolaylı ya da doğrudan mobbinge maruz kalmasına yol açabilir. Ölçme değerlendirme süreçlerinin mobbing aracı olarak kullanılması ögrencilerin okulda ve derste kendilerini tehdit altında ve aşağılanmış hissetmelerine, özgüvenlerinin zayıflamasına, stres ve tükenmişlik yaşamalarına yol açabilir.

\section{Araştırmanın Önemi ve Amacı}

İlköğretim ve ortaöğretim kurumlarındaki ölçme değerlendirme süreçleri; mesleki formasyona sahip öğretmenler tarafından, bakanlıkça merkezi olarak belirlenen eğitim programları çerçevesinde yürütülürken, yükseköğretim kurumlarında ise mesleki formasyon koşulu aranmayan öğretim elemanları tarafından özerk öğretim programları çerçevesinde yürütülmektedir. Yüksek öğretim kurumlarında görev yapan öğretim elemanları için mesleki formasyon ölçütünün olmaması ve eğitimöğretim süreçlerinin öğretim elemanları tarafından özerk bir şekilde yürütülmesi bazı durumlarda oldukça öznel ve haksız uygulamalara yol açabilir. Bu açıdan bakıldığında diğer eğitim kademeleri ile karşılaştırıldığında yükseköğretimdeki öğrencilerin ölçme ve değerlendirme süreçlerinde mobbinge maruz kalma olasılıklarının daha fazla olduğu söylenebilir. Mesleki bilgi ve beceriler kazandırmanın yanında, özgür ve bilimsel düşünebilen, sorunları bilimsel yöntemlerle çözebilen bireyler yetiştirmeyi amaçlayan (Yüksel, 2002) yükseköğretim kademesindeki öğrencilerin öznel iyi oluşları, yaşam doyumları, akademik başarı ve motivasyonları üzerinde olumsuz etkiler yaratan bir olgu olan mobbingin araştırılmasının hem kuram hem de uygulama açısından alana önemli katkılar sağlayacağı umulmaktadır. Yapılan literatür taramasında bu amaçla geliştirilen bir ölçme aracına rastlanmamış olması bu konuda yapılacak bilimsel araştırmalarda kullanılacak bir ölçme aracına duyulan ihtiyacı ortaya koymaktadır. Bu ihtiyaca binaen bu araştırma ile üniversite öğrencilerinin ölçme ve değerlendirme süreçlerinde mobbinge maruz kalma düzeylerini belirlemeyi amaçlayan geçerli, güvenilir ve kullanışlı bir ölçme aracının geliştirilmesi amaçlanmıştır.

\section{Yöntem}

\section{Desen}

Ölçek geliştirmenin amaçlandığı bu çalışma temel araştırma niteliğindedir. DeVellis (2016) ölçek geliştirme çalışmalarında izlenecek aşamaları; ölçülecek yapının açık bir şekilde ifade edilmesi, madde havuzunun oluşturulması ve ölçülecek yapının belirlenmesi şeklinde sıralalarken, Schwab (1980) bu süreci bireysel ölçek maddelerin hazırlanması, her bir maddenin uygun alt ölçeklere yerleştirilmesi ve ölçeğin psikometrik özelliklerinin test edilmesi şeklinde üç aşama halinde tanımlamaktadır. Ölçülecek kavramın tanımlanması ve ölçekteki denemelik maddelerinin hazırlanması aşaması doğası gereği nitel araştırma yöntemlerinin kullanılmasını gerektirmektedir. Buna karşın ölçeğin psikometrik özelliklerinin test edilmesi ise nicel araştırma yöntemlerinin kullanılmasını gerektirir. Bu nedenle bu araştırmada hem nitel hem de nicel yöntemin bir arada kullanıldığı karma araştırma yöntemi kullanılmıştır.

Karma yöntem araştırmaları; araştırma problem(ler)inin daha iyi analiz edilmesi için hem nitel hem de nicel verilerin eş zamanlı ya da birbirinden bağımsız olarak toplandığı, toplanan bu verilerin 
bütünleştirdiği ve daha sonrasında ise bu iki veri türünün avantajlarından faydalanılarak sonuçlar çıkarıldığı bir araştırma yaklaşımıdır (Creswell, 2017). Bu araştırmada karma yöntem araştırmaları kapsamında yer alan keşfedici sıralı ya da iki aşamalı sıralı (Creswell ve Clark, 2011) olarak adlandırılan desen kullanılmıştır. Bu desende araştırmacılar sürece nitel bir araştırma ile başlayarak katılımcıların bakış açılarını keşfetmeye çalışır, ardından bu aşamada elde edilen bilgiler nicel araştırmayı oluşturmada kullanılır (Creswell, 2014). Bu nedenle bu desen, ölçek geliştirme deseni olarak da adlandırılmaktadır (Creswell, Fetters ve Ivankova, 2004). Bu araştırmada da "Mobbing Aracı Olarak Ölçme Değerlendirme Ölçeği” nin [MAÖDÖ] geliştirilmesi sürecinde öncelikli olarak eğitimde ölçme ve değerlendirme dersini alan üniversite öğrencileriyle yapılan görüşmelerden elde edilen nitel veriler analiz edilmiş, nitel analizler sonucunda elde edilen bulgulardan hareketle denemelik madde havuzu oluşturulmuştur. Bu aşamadan sonra ise nicel veriler toplanarak ölçeğin psikometrik özellikleri test edilmiştir.

\section{Çalışma Grubu}

Araştırmaya İnönü Üniversitesi’ne bağlı 23 farkl1 MYO/Fakülte/Enstitü'de öğrenim görmekte olan 1867 öğrenci katılmıştır. Veriler öğrenci otomasyon sistemi üzerinden dijital olarak toplanmış olup öğrenim gördükleri bölüm/program ve MYO/Fakülte/Enstitüye ilişkin tutarsız bilgi veren toplam 17 öğrenci verisi iptal edilerek 1850 öğrenciye ait veriyle araştırmaya devam edilmiştir. Veri toplama sürecinin ilk bir ayında 987 öğrenci tarafından doldurulan veriler Açımlayıcı Faktör Analizi için kullanılmıştır. Açımlayıcı faktör analizi ile ilgili analizler yapıldıktan sonraki bir ay içerisinde 863 öğrenciden toplanan veriler ise Doğrulayıcı Faktör Analizi için kullanılmıştır. Her iki grupta yer alan katılımc1lara ait demografik bilgiler tablo 1'de sunulmuştur.

Tablo 1

Katılımcılara Ait Demografik Bilgiler

\begin{tabular}{llcccc}
\hline \multirow{6}{*}{ Kadın } & Değişken & Normal & $\begin{array}{c}\text { İkinci } \\
\text { Öğretim }\end{array}$ & $\begin{array}{c}\text { Uzaktan } \\
\text { Eğitim }\end{array}$ & Toplam \\
\hline \multirow{6}{*}{ Erkek } & Önlisans & 84 & 14 & 1 & 99 \\
& Lisans & 622 & 225 & 16 & 863 \\
& Lisansüstü Eğitim & 14 & 0 & 0 & 14 \\
& Toplam & 720 & 239 & 17 & 976 \\
\hline \multirow{6}{*}{ Toplam } & Önlisans & 66 & 18 & 2 & 86 \\
& Lisans & 465 & 276 & 15 & 756 \\
& Lisansüstü Eğitim & 28 & 3 & 1 & 32 \\
& Toplam & 559 & 297 & 18 & 874 \\
\hline & Önlisans & 150 & 32 & 3 & 185 \\
& Lisans & 1087 & 501 & 31 & 1619 \\
& Lisansüstü Ĕgitim & 42 & 3 & 1 & 46 \\
\hline
\end{tabular}

\section{Ölçek Maddelerinin Geliştirilmesi}

"Mobbing Aracı olarak Ölçme-Değerlendirme Ölçeği” (MAÖDÖ)'nin geliştirilmesi amaciyla öncelikle bir madde havuzu hazırlanmıştır. Bu amaçla birinci araştırmacı tarafından farklı dönemlerde, eğitim fakültesinin farklı bölümlerinde ve pedagojik formasyon programı kapsamında yürütülen eğitimde ölçme ve değerlendirme derslerinde öğrencilerle yapılan görüşmelerden derlenen notlar kullanılmıştır. Bu görüşmelerde araştırmacı öğrencilere "ölçme-değerlendirme", "not”, ya da "sinavlar" konusundaki olumlu ve/veya olumsuz deneyimlerini ya da görüşlerini ifade etmelerini 
istemiş, sıklıkla tekrar edilen ifadeleri not etmiştir. Ardından not edilen olumsuz ifadeler şiddet ve mobbing konularında çalışmaları olan Rehberlik ve Psikolojik Danışmanlık alanından iki öğretim üyesinin görüşüne sunulmuştur. Uzmanlardan ölçme ve değerlendirme süreçlerinin bir mobbing arac1 olarak kullanıldı̆̆ını ifade eden cümleleri (örn. "Maalesef sınavlardaki haksızlıkları sineye çekmek zorunda kaliyoruz.") seçmeleri istenerek bu ifadeler ölçek maddelerine dönüştürülmüştür (örn. "Madde 11. Bu bölümde sınavlardaki haksızlıkları sineye çekmek zorunda kalırız."). Bu çalışmaya ek olarak ayrıca genelde mobbing özelde de eğitimde mobbing konularına yönelik bir literatür taraması yapılmıştır. Ancak mobbingle ilgili geniş bir alan yazın olmasına rağmen eğitimde ya da ölçmedeğerlendirme süreçlerinde öğrencilerin mobbinge maruz kalmasına ilişkin bir araştırmaya ulaşılamamıştır. Yapılan literatür taraması ve uzman görüşleri 1şı̆̆ında 5'li (1=Kesinlikle katılmiyorum, 5= kesinlikle katıliyorum) Likert türünde tasarlanan 15 maddelik bir havuz oluşturulmuştur (bkz. Ek 1). Denemelik madde havuzunda yer alan maddelerden sadece biri (madde 2) tersten puanlanması gereken bir maddedir. Hazırlanan taslak ölçek formu, 2 Rehberlik ve Psikolojik Danışma, 1 Eğitim Yönetimi ve 2 Eğitimde Ölçme ve Değerlendirme uzmanının görüşüne sunularak öneriler doğrultusunda gerekli düzenlemeler yapılmıştır. Ölçeğin anlaşılabilirliğine ilişkin 20 katılımcıyla bir ön uygulama yapılarak denemelik ölçeğe son hali verilmiştir. Ölçeğin psikometrik özelliklerini incelemek amaciyla İnönü Üniversitesi'nde 23 farklı MYO/Fakülte/Enstitü'de öğrenim görmekte olan 1850 öğrenciden elde edilen veriler kullanılmıştır. Elde edilen veriler için ilk olarak maddelerin geçerli bir yapıyı oluşturup oluşturmadıklarına keşfetmek amacıyla açımlayıcı, oluşan yapının doğru olup olmadığını incelemek için de doğrulayıcı faktör analizi kullanılmıştır.

\section{Verilerin Analizi}

$\mathrm{Bu}$ araştırmada elde edilen verilerin analizinde açımlayıcı ve doğrulayıcı faktör analizi kullanılmıştır. Açımlayıcı faktör analizi için IBM SPSS 25, doğrulayıcı faktör analizi ise IBM SPSS AMOS 24 programları kullanılmıştır. Açımlayıcı ve doğrulayıcı faktör analizleri yapılmadan önce veri setlerinde eksik, hatalı ve uç veri olup olmadığı kontrol edilmiştir. Yapılan ilk incelemelerde her iki veri setinde de hatalı ve eksik veri olmadığ 1 tespit edilmiştir. Uç değerlerin tespiti için veri setlerindeki her bir maddeye ait puanlar z puanına çevrilerek standart puanlara dönüştürülmüş ve -3 ile +3 aralı̆̆ dışında kalan veri olmadığı belirlenmiştir.

Açımlayıcı faktör analizi öncesinde ölçek maddelerinin birbirleri ile örtüşüp örtüşmediğini sınamak için maddeler arasındaki korelasyon matrisi incelenmiştir. Yapılan incelemede maddeler arasındaki korelasyon katsayılarının her durumda .30'un üzerinde olduğu (Pallant, 2007, s. 187; Tabachnick ve Fidell, 2012, s. 619), ayrıca korelasyon katsayılarının .90'1 geçmediği için çoklu bağlantı sorununun olmadığı görülmüştür (Field, 2009). Maddelere ilişkin normallik analizleri çarpıklık ve basıklık değerleri ile incelenmiş ve normal dağılımdan aşırı sapma gösteren $(> \pm 1)$ üç madde $(9,10$ ve 15$)$ analiz öncesinde ölçekten çıkarılmıştır. Geriye kalan 12 madde için veri setinin örnekleme yeterliliğini test etmek amacıyla Kaiser-Meyer Olkin (KMO) ve Barlett Küresellik Testi sonuçları kullanılmış ve veri setinin faktör analizi için uygun olduğu belirlenmiştir $(\mathrm{KMO}=.934$ Barttlet=4916,256 p<.00). Verilerin madde bazında faktör analizine uygunluğunu test etmek amacıyla ayrıca korelasyon ve kovaryanslara ait görüntü önleyici matrisler (anti-image matrices) incelenmiştir. Korelasyon matrisindeki köşegen üzerindeki değerlerinin .50 'den büyük olduğu gözlemlendiği için maddelerin faktör analizine dahil edilebileceğine karar verilmiştir (Field, 2009). Faktör analizinde temel bileşenler analizi tekniğinden faydalanılmıştır. Ölçeğin iç tutarlılığını belirlemek üzere Cronbach Alfa ve Guttman Split-Half iç tutarlılık katsayıları hesaplanmıştır. Ayrıca Doğrulayıcı faktör analizi sonucunda elde edilen değerlerden hareketle ölçek maddelerinin ortalama varyans açıklama değerleri (AVE) ve kompozit güvenirlik (CR) katsayıları hesaplanmıştır. 


\section{Bulgular}

\section{Açımlayıcı Faktör Analizine İlişskin Bulgular}

Yapılan ilk faktör analizi sonucunda 12 maddenin tek bir faktör aldında yüksek yük değerleri aldığ 1 belirlenmiştir. Ancak bazı maddelere $(14,2,5,7$, ve 8$)$ ait faktör yüklerinin ve faktör ortak varyanslarının .40 'ın altında olduğu tespit edilmiştir. Bu aşamadan sonra faktör yükü ve faktör ortak varyansına ait değerler açısından en düşük değerlere sahip maddeler sırasıyla (14., 2., 7., 8. ve 5.) atılarak analizler beş kez yenilenmiştir. Yapılan son faktör analizinde geri kalan 7 madde için elde edilen yapıya ait özdeğerler ve açıklanan varyans oranları tablo 2'de, ölçeğe ait yamaç birikinti grafiği de Şekil 1'de verilmiştir.

Tablo2

Mobbing Aracı olarak Ölçme-Değerlendirme Ölçeğine ait Açılanan Varyansın Yüzdesi

\begin{tabular}{cccc}
\hline Faktör & Özdeğer & Varyans Yüzdesi & Kümülatif Yüzde \\
\hline 1 & 4.415 & 63.070 & 63.070 \\
2 & .657 & 9.384 & \\
3 & .512 & 7.310 & \\
4 & .462 & 6.599 & \\
5 & .357 & 5.101 & \\
6 & .318 & 4.537 & \\
7 & .280 & 3.999 & \\
\hline
\end{tabular}

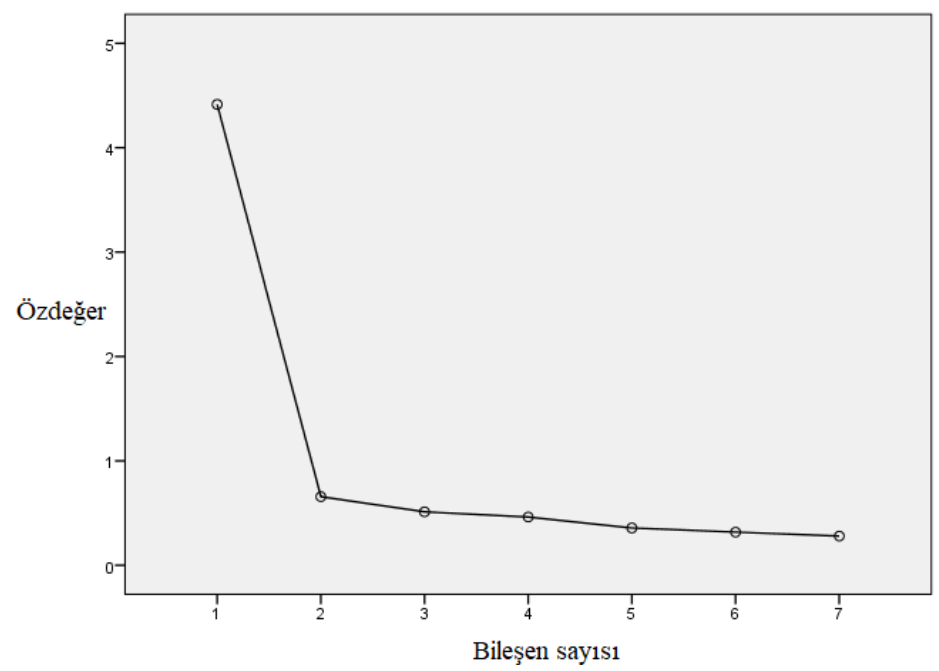

Şekil 1. Ölçeğe Ait Yamaç Birikinti Grafiği

Tablo 2 incelendiğinde sadece birinci boyuta ait öz değerin 1'in üzerinde olduğu ve bu faktör için elde edilen öz değerin ikinci faktörün öz değerinin 6 katından fazla olduğu görülmüştür. Ayrıca ölçeğe ait yamaç birikinti grafiğinde (bkz. Şekil 1) birinci faktöre ait dikey düşüşün ardından gerçekleşen dirsekleşme yapının tek boyutlu olduğunu desteklemektedir. Yedi maddelik tek faktörlü yapının ölçeğe ait toplam varyansın yaklaşık \%63'ünü açıkladığı görülmektedir. Bu oran sosyal bilimlerde tek faktörlü bir ölçek için yeterli kabul edilmiştir (Hair, Black, Babin ve Anderson, 2010). 
analizin devamında hesaplanan ölçek maddelerine ait faktör yükleri, ortak faktör yükleri ve madde toplam korelasyon katsayıları tablo 3'te verilmiştir.

Tablo 3

Tek Boyut Altında Toplanan Maddelerin Madde Faktör Yükleri ve Madde Toplam Korelasyon Katsayıları

\begin{tabular}{lcc}
\hline Madde & Faktör Yükü & $\begin{array}{c}\text { Madde-toplam } \\
\text { korelasyonu (r) }\end{array}$ \\
\hline Madde 13 & .843 & .770 \\
Madde 12 & .841 & .767 \\
Madde 03 & .804 & .725 \\
Madde 11 & .801 & .718 \\
Madde 04 & .762 & .673 \\
Madde 06 & .756 & .666 \\
Madde 01 & .745 & .652 \\
\hline
\end{tabular}

Tek faktörden oluşan yapıda maddelerin faktör yükleri .745 ile .843 arasında ve madde-toplam korelasyon (r) katsayıları ise .652 ile .770 arasında değişmektedir. Yapıyı açıklamada en çok katk1 sağlayan maddenin "Bu bölümde ögrenciler dersten kalmaktan korktukları için hiçbir şeyi eleştiremez." (13. Madde) olduğu gözlemlenmektedir. 987 kişilik veri seti için ölçeğin içtutarlılık katsayısı Cronbach Alfa $(\alpha=.902)$ ve Guttman Split-Half $(r=.878)$ yöntemleriyle incelenmiş ve ölçekten elde edilen puanların yüksek düzeyde güvenirliğe sahip olduğu belirlenmiştir.

\section{Doğrulayıcı Faktör Analizine İlişkin Bulgular}

Açımlayıcı faktör analizi ile tek boyutlu elde edilen yapıyı doğrulamak üzere 863 kişilik farklı bir veri seti ile Doğrulayıcı Faktör Analizi yapılmıştır. Yapılan ilk analiz sonucunda bazı indeksler açısından kabul edilebilir uyum iyiliği değerleri elde edilmiştir. Ancak uyum iyiliği değerleri açısından daha iyi bir ölçme modeli ortaya koyabilmek için AMOS programı tarafindan önerilen modifikasyon önerileri incelenmiştir. Yapılan incelemeler sonucunda ölçekte yer alan 3. ve 4. maddeler ile 3. ve 6 . maddeler arasında hata kovaryanslarının ilişkilendirilmesi durumunda uyum iyiliği değerlerinde anlamlı artış olacağı yönündeki öneriler dikkate alınmıştır. İlgili maddeler arasındaki hata kovaryansları ilişkilendirildikten sonra yinelenen doğrulayıcı faktör analizi sonucunda modeldeki maddelere ait standardize edilmiş yük değerlerinin .67 ile .84 arasında değiştiği ve maddelere ait $t$ değerlerinin anlamlı olduğu gözlemlenmiştir. Modele ait standardize edilmiş yük değerlerini gösteren yol diyagramı Şekil 2'de verilmiştir: 


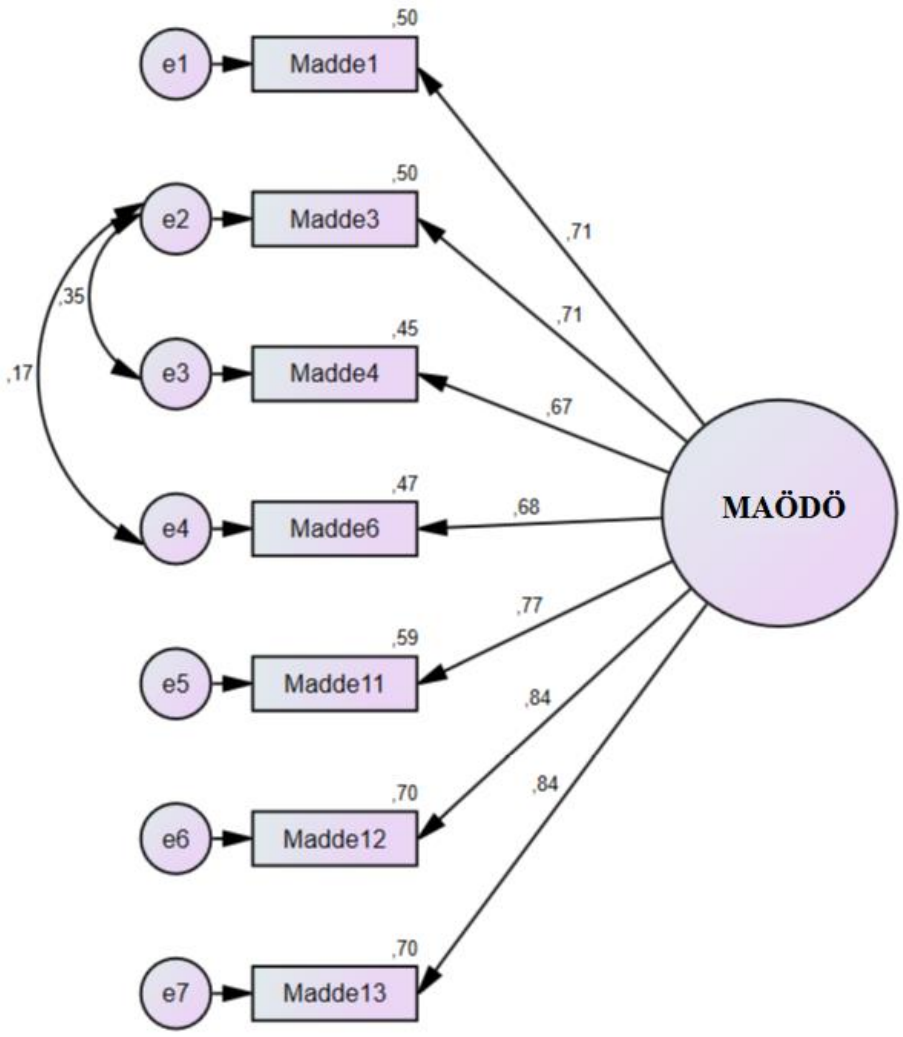

Şekil 2. Doğrulayıcı Faktör Analizine ait Standardize Edilmiş Yük Değerleri

Modelin anlamlılı̆̆ına ilişkin uyum iyiliği değerleri incelendiğinde $\left[\mathrm{X}^{2} / \mathrm{sd}=42.439 / 12=3.537\right.$; $\mathrm{RMR}=0.042 ; \mathrm{GFI}=0.986, \mathrm{AGFI}=0.968 ; \mathrm{CFI}=0.991 ; \mathrm{NFI}=0.987 ; \mathrm{RMSEA}=0.054]$ MAÖDÖ’nün yedi maddeden oluşan tek faktörlü yapısının doğrulandığı söylenebilir. Doğrulayıcı faktör analizinden elde edilen verilerden hareketle ölçek maddelerinin ortalama varyans açıklama değerleri (AVEaverage variance extracted $=.56)$ ve kompozit güvenirlik $(\mathrm{CR}$-composite reliability $=.90)$ katsayıları da hesaplanmıştır. AVE değerlerinin .50'den büyük olması ve CR katsayısının da .70'ten büyük olması yapının yakınsak (convergent) geçerliliğinin ve güvenilirliğinin bir göstergesi kabul edilmektedir (Hair, Black, Babin ve Anderson, 2010).

\section{Tartışma, Sonuç ve Öneriler}

Bu açalışmada üniversite öğrencilerinin ölçme ve değerlendirme süreçlerinde mobbinge maruz kalma düzeylerini belirlemeyi amaçlayan geçerli, güvenilir ve kullanışlı bir ölçme aracının geliştirilmesi amaçlanmıştır. Hangi eğitim kademesi olursa olsun ölçme ve değerlendirmenin adil bir şekilde yapılması öğrenciler, eğitimciler ve okullar açısından olumlu sonuçlar yaratabilirken, adil olmayan uygulamalar olumsuz etkiler yaratmaktadır. Öğrenciler eğitim ortamını şeffaf ve adil olarak algıladıklarında, duygusal açıdan daha dengeli oldukları gibi daha iyi akademik performans sergilerler. Ancak, öğrenciler kendilerine adaletsiz veya saygısız davranıldığını düşünürlerse, okuldan nefret eder, sınıfa girmekten kaçınırlar. Bu durum ise öğrencilerin akademik başarı ve motivasyonlarını düşürür, öğrencilerde depresyona ve olumsuz kişilerarası ilişkilere yol açar (Finn ve Rock, 1997; Yang, 2004). Kendilerine verilen notlar konusunda adil davranılmadığını düşünen öğrencilerin, öğretmenlerine ilişkin olumsuz tutum ve davranışlar geliştirme olasıllğı oldukça yüksektir (Tata, 1999).

Yükseköğretim kurumları eğitim sistemi açısından en üst kademeyi oluşturan ve ülkenin gelişmesi ve kalkınması için gerekli olan bilgi ve insan gücünün yetiştirildiği kurumlardır (Gedikoğlu, 2005). Yükseköğretim kurumları öğretim üyelerinin/elemanlarının bilimsel araştırmalar yapma (Çivilidağ, 2011) ve bireylere mesleki bilgi kazandırmanın yanında; özgür ve bilimsel düşünebilen, sorunları bilimsel yöntemlerle çözebilen bireyler yetiştirmeyi amaçlamaktadır (Yüksel, 2002). Bu amacın gerçekleşebilmesi için öğretim elemanları tarafından sunulan öğretim hizmetlerinin niteliği oldukça önemlidir. Yüksek öğretim kademesinde sunulan öğretim hizmetlerinin niteliğine ilişkin 
göstergelerden biri de ölçme-değerlendirme süreçleridir. Öğretim elemanları derslerinin gereği olarak öğrencilerine notlar vermektedir. Notlandırma, öğretmenlerin öğrencilerin öğrenmesi, başarısı ve gelişimi konusunda değerlendirme yapmalarını gerektiren karmaşık ve uzmanlık gerektiren bir karar verme sürecidir (Sun ve Cheng, 2014). Ancak yükseköğretimde görev yapan çoğu öğretim elemanı öğretime ilişkin mesleki formasyon sahibi olmadığından, bu kademede eğitim-öğretim süreçlerinin yönetimi ve değerlendirilmesi konusunda sorunlar yaşanabilmektedir. Öğretim elemanlarının eğitimöğretim konusundaki pedagojik yetersizlikleri derslerde etkisiz öğretim yöntem ve tekniklerinin kullanılmasına yol açabilmektedir. $\mathrm{Bu}$ yetersizliklerin hatalı ve keyfi ölçme-değerlendirme uygulamaları ile birleşerek sürece yayılması öğrenciler üzerinde birçok olumsuz etkiye yol açabilmektedir. Adaletsiz ölçme ve değerlendirme uygulamalarının sürekli olması ve yetki hiyerarşisinde öğrencinin üstü konumdaki öğretim elemanları tarafindan yapılması ölçmedeğerlendirme uygulamalarının aynı zamanda mobbing olarak algılanmasına yol açabilir. Mobbing üniversite öğrencilerinin yaşam doyumları, üniversite memnuniyeti, akademik başarı ve motivasyon gibi özellikleri üzerinde olumsuz etkileri olan bir olgudur. Mobbinge maruz kalan bireyler kendisini stres altında, tehdit edilmiş, aşağılanmış hisseder ve özgüvenleri zayıflar (Tutar, 2004). Bu durum yükseköğretimin özgür ve bilimsel düşünebilen bireyler yetiştirme hedefleriyle çelişmektedir. Dolayısıla öğrenciler üzerinde mobbinge neden olabilecek başta ölçme ve değerlendirme süreçleri olmak üzere bütün etmenlerin tespit edilerek giderilmesi gerekmektedir. Bu nedenle bu araştırmada öğrenme süreçlerinin ve sonuçlarının niteliğinin izlenmesi amacıyla kullanılan ölçme ve değerlendirme araçları ve yöntemlerindeki yanlış uygulamaların öğrenciye psikolojik yıldırma (mobbing) olarak nasıl yansıyabileceği ele alınmış, bu durumu ölçebilecek geçerli ve güvenilir bir ölçme aracı geliştirilmeye çalışılmıştır.

Bu amaçla "Mobbing Aracı olarak Ölçme-Değerlendirme Ölçeği"nin maddeleri nitel bir veri toplama ve analiz süreci ile geliştirilmiş ve ardından psikometrik özellikleri nicel yöntemlerle incelenmiştir. Yapılan açımlayıcı faktör analizi sonucunda tek faktörden oluşan ölçeğin iyi düzeyde varyans açıklama oranına (\%63), yüksek faktör yük değerlerine (.745-.843) ve madde-toplam korelasyon katsayılarına $(\mathrm{r}=.652-.770)$ sahip olduğu görülmüştür. Devamında yapılan doğrulayıcı faktör analizinde ise yapının model ile uyumlu olduğu anlaşı1mıştır $\left[\mathrm{x}^{2} / \mathrm{sd}=42.439 / 12=3.537\right.$; RMR= 0.042; GFI $=0.986, \mathrm{AGFI}=0.968 ; \mathrm{CFI}=0.991 ; \mathrm{NFI}=0.987 ; \mathrm{RMSEA}=0.054] . \mathrm{Bu}$ değerlerden $\mathrm{X}^{2} / \mathrm{sd}$ değerinin 3'ün (Kline, 2005) veya 2'nin altında olması (Tabachnick ve Fidel, 2007) mükemmel bir uyum olduğunu gösterirken, 5 ve altında olması kabul edilebilir bir uyumu göstermektedir. RMR ve RMSEA değerlerinin 0,06 veya daha küçük olması, CFI, GFI, AGFI ve NFI değerlerinin 0,95 üzerinde olması geliştirilen model ile yapının mükemmel bir uyuma sahip olduğunu göstermektedir (Hu ve Bentler, 1999). Ayrıca ölçek maddelerinin ortalama varyans açıklama değerleri (AVE = .56) ve kompozit güvenirlik $(\mathrm{CR}=.90)$ katsayılarından hareketle yapının yakınsak geçerliliğinin ve güvenilirliğinin yeterli olduğu anlaşılmıştır (Hair, Black, Babin ve Anderson, 2010). Ölçeğin Cronbach Alfa $(\alpha=.902)$ ve Guttman test yarılama $(r=.878)$ yöntemleriyle hesaplanan içtutarlılık katsayıları da ölçekten elde edilen puanların yüksek düzeyde güvenirliğe sahip olduğunu göstermektedir (Nunnally ve Bernstein, 1994). Toplam 7 maddeden oluşan 5'li Likert formatındaki "Mobbing Aracı olarak Ölçme-Değerlendirme Ölçeği"nden alınan minimum ve maksimum puanlar 735 arasında değişmekte olup cevap seçenekleri ve puan karşılıkları Kesinlikle Katılmıyorum (1 puan), Katılmıyorum ( 2 puan), Kismen kat1lıyorum ( 3 puan), Kat1lıyorum (4 puan) ve Kesinlikle Kat1liyorum (5 puan) şeklindedir. Ölçeğin nihai formunda tersten puanlanması gereken madde bulunmamaktadır. Alınan puanların artması öğrencilerin ölçme değerlendirme aracıllı̆ıyla mobbinge maruz kalma düzeylerinin de arttığını göstermektedir.

Elde edilen bu bulgulardan hareketle "Mobbing Aracı olarak Ölçme-Değerlendirme Ölçeği"nin yüksek düzeyde geçerliliğe ve güvenilirliğe sahip olduğu, yedi maddeden oluşan kısa formun öğrenciler tarafından elle ya da dijital ortamlarda hızlı bir şekilde doldurulabildiği için oldukça kullanışlı olduğu söylenebilir. Geliştirilen "Mobbing Aracı olarak Ölçme-Değerlendirme Ölçeği”" gerek kurumsal olarak gerekse bireysel olarak yükseköğretim düzeyinde iç ve diş kalite değerlendirme süreçlerinde veri toplamak amacıyla kullanılabilir. Ayrıca araştırmacılar üniversite öğrencilerinin öznel iyi oluş, yaşam doyumu, yaşam kalitesi, üniversite memnuniyeti, okula yabancılaşma, akademik motivasyon vb. özellikleriyle arasındaki ilişkiyi test etmek için ölçeği kullanabilirler. 
Ek 1. Mobbing Aracı Olarak Ölçme ve Değerlendirme Ölçeği Madde Havuzu

1) Bu bölümde öğretim elemanlarının sınavlarına itiraz etmek cesaret ister.

2) Bu bölümde sınavların hakkaniyetli bir şekilde yapıldığını düşünüyorum.*

3) Bu bölümde öğretim elemanları notu bir tehdit/korkutma aracı olarak kullanır.

4) Bu bölümde sınavların öğrencileri cezalandırmak için kullanıldığını düşünüyorum.

5) Bu bölümde bazı öğrencilerin sınavlarda açıkça kayırıldığını söyleyebilirim.

6) Bu bölümde hoca bir öğrenciye kafayı taktıysa o öğrencinin dersten geçmesi çok zordur.

7) Bu bölümde hocaların sınavda hangi konudan ne soracağı belli olmaz.

8) Bu bölümde hocalar derste işlemedikleri konulardan da sorular sorarlar.

9) Bu bölümde not bir taciz aracı olarak kullanılır.

10) Bu bölümde not bir şantaj aracı olarak kullanır.

11) Bu bölümde sınavlardaki haksızlıkları sineye çekmek zorunda kalırız

12) Bu bölümdeki hocalar sınavlarla ilgili eleştirilere açık değildir.

13) Bu bölümde öğrenciler dersten kalmaktan korktukları için hiçbir şeyi eleştiremez.

14) Bu bölümde öğrenciyi dersten bırakmak için sinavda kasıtlı olarak zor sorular sorulur.

15) Bu bölümdeki öğretim elemanları notu bir istismar aracı olarak kullanır.

* Tersten puanlanmas1 gereken madde.

Not: Koyu renkte yazılan maddeler ölçeğin nihai formunda yer almıştır. 


\section{Kaynaklar}

Adediwura, A.A. (2012). Students' self-efficacy and self-autonomy in the learning of mathematics. Gender and Behaviour, 10(1), 4492-4508.

Akgeyik, T., Güngör-Delen, M. ve Uşen, Ş. (2013). Çalışma yaşamında psikolojik taciz. Ankara: Özyurt Matbaac1lik.

Bahar, M., Nartgün, Z., Durmuş, S. ve Bıçak, B. (2012). Geleneksel-tamamlayıcı ölçme ve değerlendirme teknikleri ögretmen el kitabı. Ankara: Pegem Akademi.

British Broadcasting Corporation, (BBC, 2019, Nisan) Ceren Damar cinayeti: Zanlının kopya çekmekten aldığı ilk ceza değil. 12.04.2019 tarihinde https://www.bbc.com/turkce/haberlerturkiye-46758890 adresinden alınmıştır.

Birenbaum, M. (2007). Evaluating the assessment: sources of evidence for quality assurance. Studies in Educational Evaluation, 33, 29-49.

Birjandi, P. and Tamjid, N.H. (2012). The role of self-, peer and teacher assessment in promoting Iranian EFL learners' writing performance. Assessment and Evaluation in Higher Education, 37(5), 513-533.

Black, P. and William, D. (1998). Inside the black box, raising standards through classroom assessment. Phi Delta Kappan, 80(2), 139-148.

Büyüköztürk, Ş., Çakmak, E. K., Akgün, Ö. E., Karadeniz, Ş. ve Demirel, F. (2012). Bilimsel araştırma yöntemleri. Ankara: Pegem Akademi Yayımcılık.

Broadfoot, P. and Black, P. (2004). Redefining assessment? The first ten years of assessment in education. Assessment in Education: Principles, Policy and Practice, 11(1), 7-26.

Cihanoğlu, M.O. (2008). Alternatif değerlendirme yaklaşımlarından öz ve akran değerlendirmenin işbirlikli öğrenme ortamlarında akademik başarı, tutum ve kalıcılı̆̆a etkileri. Doktora Tezi. Dokuz Eylül Üniversitesi, Eğitim Bilimleri Enstitüsü, İzmir.

Cable News Network Türk, (CNN TÜRK, 2019, Nisan), Ankara Üniversitesi, cinsel taciz ve saldırıları araştıracak. Erişim: https://www.cnnturk.com/yerel-haberler/ankara/ankara-universitesi-cinseltaciz-ve-saldirilari-arastiracak-975107 adresinden alınmıştır.

Creswell, J. W. (2014). Araştırma deseni: Nitel, nicel ve karma yöntem yaklaşımları (Çev. Ed: S. B. Demir). Ankara: Eğiten Kitap.

Creswell, J. W. (2017). Karma yöntem araştırmalarına girişs (Çev. Ed. M. Sözbilir), Ankara: Pegem Akademi.

Creswell, J. W. and Clark, V.L.P. (2011). Designing and conducting mixed methods research (2 ${ }^{\text {nd }}$ Ed.). Thousand Oaks, CA: Sage Publications.

Creswell, J.W., Fetters, M.D. and Ivankova, N. V. (2004). Designing a mixed methods study in primary care. Annals of Family Medicine, 2(1), 7-12.

Çamurluoğlu, M. İ. and Poussard, J.M. (2017). Psikolojik taciz: Türkiye genelinde bir araştırma. Finans Politik ve Ekonomik Yorumlar, 624(54), 53-68 
Çivilidağ, A. (2011). Üniversitelerdeki öğretim elemanlarının psikolojik taciz (mobbing), iş doyumu ve algllanan sosyal destek düzeyleri. Doktora Tezi. Selçuk Üniversitesi, Eğitim Bilimleri Enstitüsü, Konya.

DeVellis, R. F. (2016). Scale development theory and applications. Los Angeles: SAGE Publication.

Elkıran, M. C. (2017). Akademisyenlerin algıladıkları yıldırma (mobbing) davranışları ile yöneticilerin liderlik davranışları arasındaki ilişki. Yüksek Lisans Tezi. Çanakkale Onsekiz Mart Üniversitesi, Eğitim Bilimleri Enstitüsü, Çanakkale.

Erdemir, S. (2013). İlköğretim ögretmenlerinin duygusal zeka düzeyleri ile yaşadıkları psikolojik yıldırma (Mobbıng) arasındaki ilişki üzerine bir araştırma. Yüksek Lisans Tezi. Gaziantep Üniversitesi, Eğitim Bilimleri Enstitüsü, Gaziantep.

Erdemir, S. ve Murat, M. (2014). İlköğretim öğretmenlerinin duygusal zekâ düzeyleri ile yaşadıkları psikolojik yıldırma arasındaki ilişkinin incelenmesi. Mustafa Kemal Üniversitesi Sosyal Bilimler Enstitüsü Dergisi, 11(25), 323-340.

Field, A. (2009). Discovering statistics using SPSS. London: Sage Publication Ltd.

Finn, J. D. and Rock, D.A., (1997). Academic success among students at risk for school failure. Journal Applied Psychology 82(2), 221-234

Gedikoğlu, T. (2005). Avrupa Birliği sürecinde Türk eğitim sistemi: Sorunlar ve çözüm önerileri. Mersin Üniversitesi Eğitim Fakültesi Dergisi, 1(1), 66-80.

Gün, H. (2010). Çalışma ortamında psikolojik taciz. Ankara: Lazer Yayınları.

Hair, J.F., Black, W.C., Babin, B. J. and Anderson, R. E. (2010). Multivariate data analysis: A global perspective. Upper Saddle River, NJ: Pearson.

Hu, L., \& Bentler, P.M. (1999). Cutoff criteria for fit indexes in covariance structure analysis: Conventional criteria versus new alternatives. Structural Equation Modeling, 6, 1-55.

İnönü Üniversitesi (2019). İstatistiksel veriler. İnönü üniversitesi öğrenci işleri daire başkanlığ1 28.08.2019 tarihinde http://inonu.edu.tr/tr/ogrenci/1337/menu?m=11332 adresinden alınmıştır.

Karakoç, N. (2012). Öğretim elemanlarının yıldırma davranışlarına maruz kalma durumu ve örgütsel bağlılığının incelenmesi. Yüksek Lisans Tezi. Ege Üniversitesi, Sosyal Bilimler Enstitüsü, İzmir.

Kline, R. B. (2005). Principles and practice of structural equation modeling. New York: The Guilford Press.

Laleoğlu, A. ve Özmete, E. (2013). Mobbing ölçeği: Geçerlik ve güvenirlik çalışması. Sosyal Politika Çalışmaları Dergisi, 7(31), 9-31.

Leymann, H. (1996). The content and development of mobbing at work. European Journal of Work and Organizational Psychology, 5(2), 165-184.

Mok, J. (2010). Acase study of students' perceptions of peer assessment in Hong Kong. ELT Journal, 65(3), 230-239.

Nunnally, J. C., and Bernstein, I. H. (1994). Psychometric theory. New York: McGraw-Hill 
Oskarsson M. (1981). Subjective and objective assessment of foreign language performance. (J. Read, Ed.) Directions in language testing (pp. 225-239) Singapore: Seameo Regional Language Centre.

Pallant, J. (2007). Spss survival manual. Sydney: Allen and Unwin.

Ploegh, K., Tillema, H.H. ve Segers, S. (2009). In search of quality criteria in peer assessment practices. Studies in Educational Evaluation, 35, 102-109.

Saraç, E. (2018). Hemşirelerde mobbingin anksiyete düzeyi ile ilişkisi. Yüksek Lisans Tezi. Süleyman Demirel Üniversitesi, Sosyal Bilimler Enstitüsü, Isparta.

Sarı, E.G. (2018). Akademisyenlerin mobbing algılarının örgütsel yabancılaşma düzeyleri ile ilişkisi (Munzur Üniversitesi Örneği). Yüksek Lisans Tezi. Mehmet Akif Ersoy Üniversitesi, Eğitim Bilimleri Enstitüsü. Burdur.

Schwab, D. P. (1980). Construct validity in organization behavior. In B. M. Staw \& L. L. Cummings (Eds.), Research in organizational behavior (Vol. 2, pp. 3-43). Greenwich, CT: JAI Press.

Sun, Y. and Cheng, L. (2014). Teachers' grading practices: Meaning and values assigned. Assessment in Education: Principles, Policy \& Practice, 21(3), 326-343.

Sung, Y-T., Chang K-E, Chiou S-K. and Hou H-T. (2005). The design and application of a web-based self- and peer-assessment system. Computers and Education, 45, 187-202.

Tabachnick, B.G. and Fidell, L.S. (2014). Using multivariate statistics. London: Pearson.

Tata, J. (1999). Grade distributions, grading procedures, and students' evaluations of instructors: A justice perspective. The Journal of Psychology, 133(3), 263-271.

Taştan, T. (2017). Hemşirelikte mobbing yaşama durumunun kurumsal bağlllık ve kurumsal güvene etkisi. Yüksek Lisans Tezi. Ondokuz Mayıs Üniversitesi, Sağlık Bilimleri Enstitüsü, Samsun.

Tınaz, P., Bayram, F. ve Ergin, H. (2008). Çalı̧̧ma psikolojisi ve hukuki boyutlarıyla işyerinde psikolojik taciz. İstanbul: Beta Yayınları.

Topping, K. (1998). Peer Assessment between students in colleges and universities. Review of Educational Research, 68(3), 249-276.

Topping K. J., Smith, E.F., Swanson, I. and Elliot A. (2000). Formative peer assessment of academic writing between postgraduate students. Assessment and Evaluation in Higher Education, 25(2), 149-169.

Torrance, H. and Pryor, J. (1998). Investigating formative assesment: Teaching learning and assesment in classroom. Open University Press. Philadelphia

Tutar, H. (2004). Iş̧ yerinde psikolojik şiddet. Ankara: Platin Yayınları.

Uysal, K. (2008). Öğrencilerin ölçme değerlendirme sürecine katılması: akran değerlendirme ve öz değerlendirme. Yüksek Lisans Tezi. Abant İzzet Baysal Üniversitesi, Sosyal Bilimler Enstitüsü, Bolu.

Wen, M. L. and Tsai, C. C. (2006). University students' perceptions of and attitudes toward (online) peer assessment. Higher Education, 51, 27-44. 
Yang, H. J. (2004). Factors affecting student burnout and academic achievement in multiple enrollment programs in Taiwan's technical-vocational colleges. International Journal of Educational Development, 24(3), 283-301.

Yurdabakan, İ. (2012). Ortak ve akran değerlendirme eğitiminin öğretmen adaylarının özdeğerlendirme becerileri üzerine etkisi. Ĕ̈itim ve Bilim, 163(37), 190-202.

Yüksel, S. (2002). Yükseköğretimde eğitim-öğretim faaliyetleri ve örtük program. Uludăg Üniversitesi Eğitim Fakültesi Dergisi, 15(1), 361-370. 


\section{Extended Abstract}

\section{Introduction}

Measurement and evaluation methods and tools as used to determine the level of learning outcomes at different stages of the education. Based on the information obtained from the measurement and evaluation, furher decisions are made about students, teachers, schools and curricula and future policies are determined. Introduction of contemporary measurement and assessment notion into the field in addition to the traditional approach has led to a wider and more detailed spectrum of measurement and evaluation methods and tools. This, in turn, has necessitated the use of measurement and assessment tools and methods in a much more elaborate manner. Therefore, a need for better criteria for the proper conduct of measurement and evaluation processes emerged. One of these criteria is the competence of faculty in tetrms of measurement and evaluation. A teacher with sufficient pedagogical competence in assessment is expected to be able to distinguish between traditional and contemporary assessment approaches and apply both approaches correctly in their lesson plans. However, the pedagogical insufficiency of the faculty staff can turn the measurement and evaluation process into a means of pressure or punishment on students. An instructor who does not carry out the measurement and evaluation processes in line with scientific principles may possibiliy discriminate between students in the exams, prepare the exams too difficult or keep the exam time too short, ask questions not representing the actual course contents, threaten the students with grades or overreact to the students criticizing the exam. It can be said that when become persistent these practices may turn into mobbing, either explicitly or implicitly, causing the student to feel threatened and humiliated, to weaken their self-confidence and remain under intense stress. It can be expected that higher education students are more likely to be exposed to mobbing through the measurement and evaluation processes, since the development of curriculum and instructional procedures are carried out by faculty staff most of whom have not gone through a formal pedagogical formation process. For this purpose, there was a need to develop a measurement tool to be used to determine the levels of exposure to mobbing in the measurement and evaluation processes of university students.

\section{Method}

This research, which aims to develop a valid, reliable and useful scale that can measure the university students' levels of exposure to mobbing through measurement and evaluation processes, has been designed as a mixed method research. To this end, the items of "Mobbing through Measurement and Evaluation Scale" [MMES] were developed through a qualitative data collection and analysis process, and its psychometric properties were analyzed with the data obtained from 1850 students studying at 23 different Vocational Schools/Faculties/Institutes of İnönü University. For this purpose, data initially obtained from 987 people were used for exploratory factor analysis, and data succesively collected from 863 people were subjected to confirmatory factor analysis.

\section{Results}

The exploratory factor analysis yielded a single factor construct with a good variance explanation rate $(63 \%)$, high factor loading values $(.745-.843)$ and item-total correlation coefficients $(\mathrm{r}=.652-.770)$; and the successive confirmatory factor analysis proved that the construct was confirmed by acceptable or excellent goodness of fit values $\left[\mathrm{X}^{2} / \mathrm{df}=42.439 / 12=3.537\right.$; $\mathrm{RMR}=$ 0.042; GFI $=0.986 ;$ AGFI $=0.968 ; \mathrm{CFI}=0.991 ; \mathrm{NFI}=0.987 ; \mathrm{RMSEA}=0.054]$. In addition, average variance explanation value $(\mathrm{AVE}=.56)$ and composite reliability $(\mathrm{CR}=.90)$ coefficients suggested that the convergent validity and reliability of the structure was sufficient. The Cronbach's alpha $(\alpha=$ $.902)$ and Guttman split-half $(r=.878)$ reliability coefficients of the scale indicated that the scores obtained from the scale have a high level of reliability. The minimum and maximum scores obtained from the 7-item 5-point Likert format ranged between 7 and 35 suggesting that the increase in the scores implies that the students' levels of exposure to mobbing through assessment also increases. 


\section{Discussion and Conclusion}

Within the Turkish education system, higher education institutions constitute the highest stage where the necessary knowledge and manpower is produced for the development of the country. In addition to conducting scientific researches and providing professional knowledge to individuals, it also aims to educate individuals who can think in a free and scientific manner and solve problems through scientific method. Attaining these objectives depends on the quality of instruction offered by the faculty staff. However, in the higher education level, the development of curricula and the conduct of teaching activities are carried out by faculty members most of whom have not gone through a formal pedagogical formation process. If these skills are not acquired through in-service trainings or personal professional development efforts, instructors cannot be expected to plan their courses in accordance with pedagogical principles, use effective teaching strategies, methods and techniques, or apply accurate and effective measurement and evaluation procedures to support and monitor the quality of teaching and learning processes. However, the misuse or abuse of these measurement and evaluation procedures can cause mobbing on students. In this research, a measurement tool has been developed to measure the level of exposure to such mobbing. Considering that mobbing is a variable that can negatively associated with such characteristics of individuals as well-being, life satisfaction, quality of life, university satisfaction, alienation from school, academic motivation, it is essential to develop a valid, reliable and useful tool to determine the level of exposure of university students to such an abuse. 